\title{
Removal of crystal violet from aqueous solutions using an aerobic granular sludge system
}

\author{
COSTEL BUMBAC**, ELENA ELISABETA MANEA, OLGA TIRON
}

National Research and Development Institute for Industrial Ecology - ECOIND, 57-73 Drumul Podu Dambovitei, 060652, Bucharest, Romania

*Corresponding author: costel.bumbac@incdecoind.ro

$\begin{array}{lll}\text { Received: } & \text { Accepted: } & \text { Published: } \\ \text { 15.06.2021 } & 20.06 .2021 & 25.06 .2021\end{array}$

\section{Abstract}

The paper presents a set of comparative tests to evaluate the inhibitory effect of crystal violet on the respiration rate of microorganisms in conventional activated sludge and aerobic granular sludge. The tests were performed in similar conditions with the only variable of the type of sludge tested. The results emphasized that the aerobic granular sludge is less susceptible to the toxicity induced by crystal violet. The concentration of crystal violet that inhibits by $50 \%\left(C E_{50}\right)$ the respiration rate of sludge microorganisms was determined to be, for the specific test conditions, $22.39 \mathrm{mg} / \mathrm{L}$ for the conventional activated sludge and 33.88 $\mathrm{mg} / \mathrm{L}$ for the aerobic granular sludge. The paper also assesses the biodegradability potential of crystal violet from aqueous solution, in the presence of sodium acetate as co-substrate in a lab-scale sequential biological reactor with aerobic granular sludge. The experiments showed that most of the crystal violet is being initially absorbed in the matrix of the granules during the first minutes and subsequently is being removed with efficiencies above $95 \%$ within a treatment cycle of 8 hours.

Keywords: aerobic granular sludge, Cristal Violet, wastewater treatment, inhibition test

\section{INTRODUCTION}

Crystal violet $(\mathrm{CV})$ or gentian violet, also known as methyl violet 10B or hexamethyl pararosaniline chloride, is a triarylmethane dye used as a histological stain and in Gram's method of classifying bacteria. Crystal violet is a toxic and inhibitory substrate, with a high capacity to penetrate the cell walls of microorganisms and has antibacterial, antifungal, and antihelmintic properties [1, 2]. Crystal violet class dyes are also widely used in the textile industry, paper printing, detergents, leather staining, additive in poultry feed, etc. [3, 4].

However, due to poor management of wastewater containing CV from industries, this pollutant is frequently detected in surface waters [5].

Since its use comes with the responsibility of dealing properly with the effluents containing crystal violet dyes, during the last 30 years many treatment technologies have been developed tested, and applied including physical, chemical, and biological techniques [6-8]. Most of the used treatment processes include wet air oxidation, catalytic processes, biochemical processes, biological processes, and physical adsorption for the removal of dyes from the aquatic environment [9-11]. Since most of the dyes, including crystal violet, have high toxicity and low biodegradability, most biological treatments are focused on technologies such as biosorption [12-14] and very few studies are addressing the biological degradation of the pollutant in systems using either specific strains of bacteria such as Agrobacterium radiobacter [15] or Bacillus sp. [16], either different strains of fungus such as white-rot fungus Phanerocheate chrysosporium [17] or Pleurotus ostreatus [18].

There is limited data on the occurrence, fate, and impact of crystal violet dyes on wastewater treatment processes and sludge viability. Some studies are reporting the use of waste-activated sludge powders as adsorbent materials for crystal violet removal from wastewaters [19, 20].

This study focused on assessing the potential impact of crystal violet on the microorganisms of the activated sludge by assessing comparatively the $\mathrm{CE}_{50}$ concentration of crystal violet inhibiting the 
respiration of conventional and aerobic granular sludge. Furthermore, a set of biodegradation experiments were performed to assess $\mathrm{CV}$ biodegradation potential in a lab-scale aerobic granular sludge sequential biological reactor.

\section{EXPERIMENTAL PART}

\section{Activated sludge inhibition tests}

Activated sludge inhibition tests were performed according to SR EN ISO 8192:2007 Water quality - Test for inhibition of oxygen consumption by activated sludge for carbonaceous and ammonium oxidation to assess the concentration of Crystal violet inhibiting by $50 \%$ the respiration rate of activated sludge and the difference in $\mathrm{CE}_{50}$ of crystal violet for conventional activated sludge and aerobic granular sludge. The tests were run comparatively using the same experimental conditions on two different types of sludges: conventional activated sludge and aerobic granular sludge. The experimental conditions included for both experiments a set of test samples with different concentrations of Crystal Violet ranging from 10 to $50 \mathrm{mg} / \mathrm{L}$. Tested concentration series were as follows: $10,15,20,25,30,40$, and $50 \mathrm{mg} / \mathrm{L}$, respectively.

The conventional sludge was sourced from a municipal wastewater treatment plant while the aerobic granular sludge was sampled from a lab-scale sequential biological reactor (SBR) fed with synthetic wastewater based on acetate as a carbon source. Both sludges were washed and prepared according to standard before use. Experiments were performed at room temperature $\left(22^{\circ} \mathrm{C} \pm 2{ }^{\circ} \mathrm{C}\right)$, under stirred conditions (multiple magnetic stirrers) while the dissolved oxygen concentration was monitored every 30 minutes for 180 minutes using the oximeter WTW Oxi 320 with CellOx325. Oxygen consumption rates in each sample, biological control, and abiotic control were calculated according to standard based on the oxygen concentration measurements while the $\left(\mathrm{CE}_{50}\right)$ concentration of crystal violet inhibiting by 50\% the respiration rate of the sludge was estimated by interpolating on the graph according to standard procedure.

\section{Discoloration experiments}

The experiments were designed to assess the potential of using a wastewater treatment system with aerobic granular sludge operated in sequential biological conditions to evaluate the discoloration potential of Crystal Violet in a lab-scale treatment system in the presence of co-substrate (sodium acetate).

The experiments were performed in a 5 liters column type reactor (figure 1) fitted with a programable logic controller (PLC) able to ensure the filling-reaction-settling-discharge steps of the SBR operation according to the following time sequence: filling - $10 \mathrm{~min}$, aeration - $455 \mathrm{~min}$, settling - 5 min, emptying - 10 min.

The bioreactor was fed with an adapted synthetic medium [5] containing: $2 \mathrm{~g} / \mathrm{L}$ sodium acetate, 0.2 $\mathrm{g} / \mathrm{L} \mathrm{NH} 4 \mathrm{Cl} ; 0.08 \mathrm{~g} / \mathrm{L} \mathrm{K}_{2} \mathrm{HPO}_{3} \cdot 3 \mathrm{H}_{2} \mathrm{O} ; 0.02 \mathrm{~g} / \mathrm{L} \mathrm{CaCl}_{2} ; 0.03 \mathrm{~g} / \mathrm{L} \mathrm{MgSO} \boldsymbol{M ~}_{4} \cdot 7 \mathrm{H}_{2} \mathrm{O} ; 0.02 \mathrm{~g} / \mathrm{L} \mathrm{FeSO}_{4} \cdot$ $7 \mathrm{H}_{2} \mathrm{O}$. The influent was spiked with Crystal Violet in concentrations of up to $15 \mathrm{mg} / \mathrm{L}$. The sequential bioreactor was tested for water with dye in increasing concentration but below the determined $\mathrm{CE}_{50}$. 


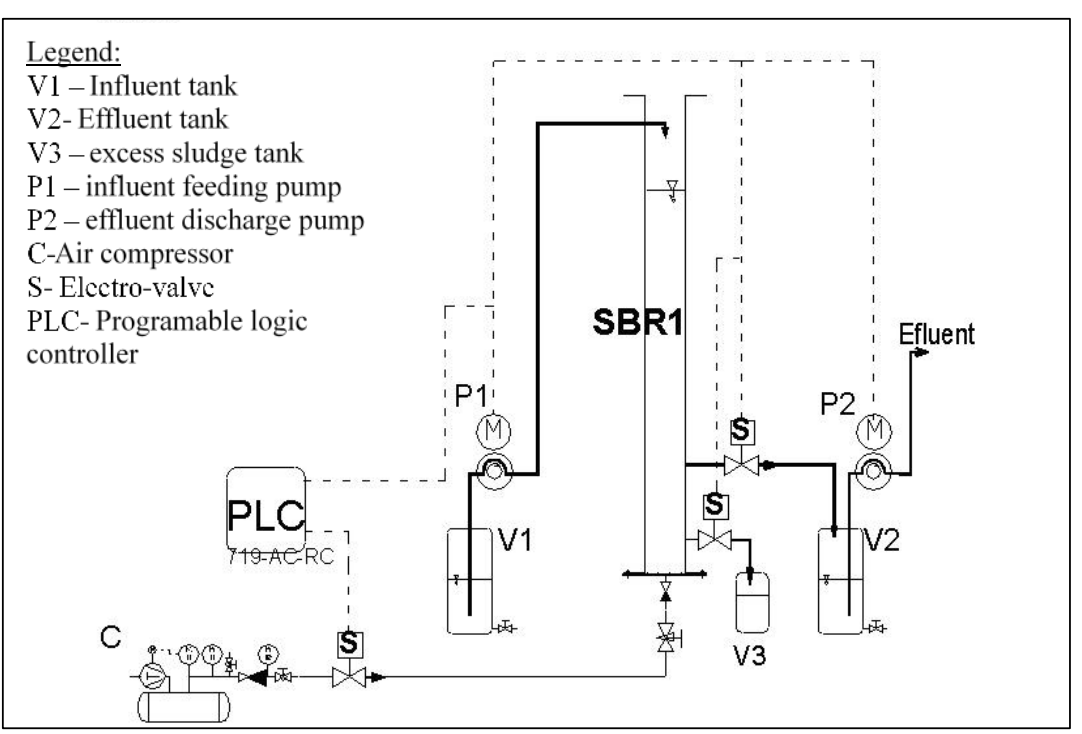

(a)

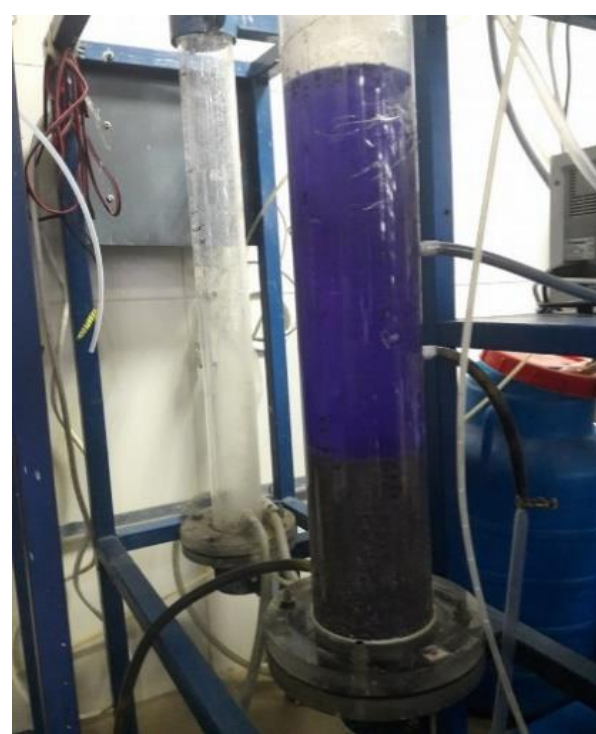

(b)

Fig. 1. a) Logic diagram of the sequential micropilot installation, b) The overall image of the reactor during feeding

\section{RESULTS AND DISCUSSION}

Activated sludge inhibition tests

The evolutions of oxygen concentration in all test and control samples, for each of the tested variants, are presented in figure 2. For the tests on conventional activated sludge, the oxygen consumption rates ranged from $2.49 \mathrm{mg} / \mathrm{Lh}$ for the biological control sample to $0.27 \mathrm{mg} / \mathrm{Lh}$ for the sample with the highest concentration of crystal violet $(50 \mathrm{mg} / \mathrm{L})$.

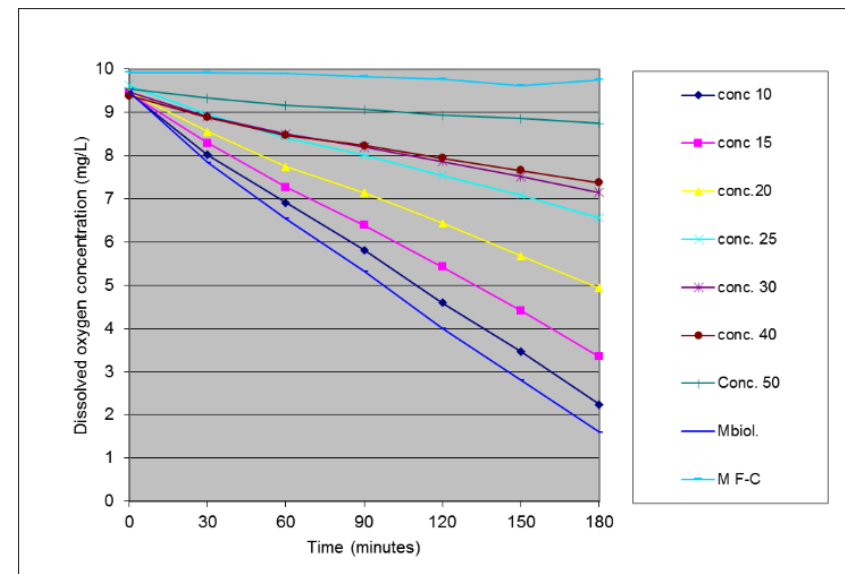

a)

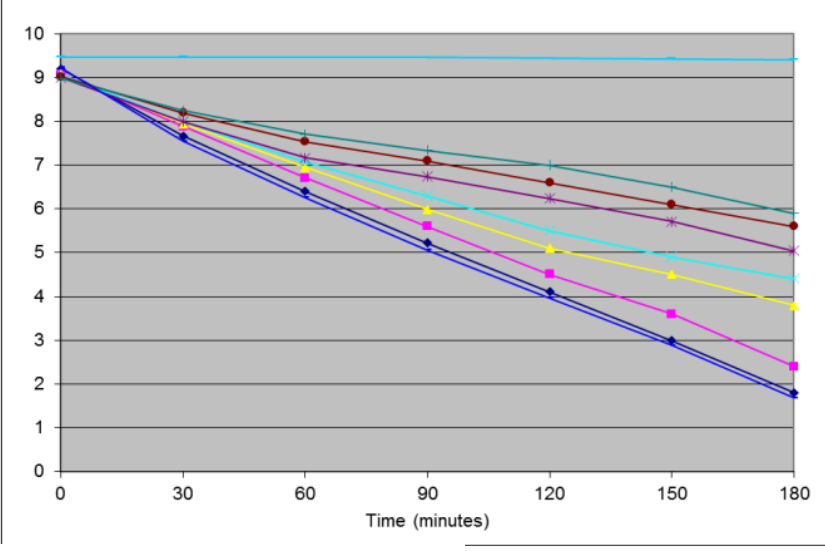

b)

Fig. 2. The evolution of dissolved oxygen concentration for each of the test samples and controls for activated sludge inhibition

( $\mathrm{a}$ - results for conventional activated sludge; $\mathrm{b}$ - results for aerobic granular sludge)

There was a gradual decrease in the rate of oxygen consumption in the test vessels with increasing concentration of crystal violet and thus an increase in the percentage of respiratory inhibition with increasing concentration of the test compound, from 6.5 to $92 \%$ (figure $3 \mathrm{a}$ ). On the other hand, the experiment performed in similar conditions on aerobic granular sludge showed oxygen consumption rates ranging from $2.52 \mathrm{mg} / \mathrm{Lh}$ for the biological control sample to $1.03 \mathrm{mg} / \mathrm{Lh}$ for the sample with the highest concentration of crystal violet $(50 \mathrm{mg} / \mathrm{L})$ corresponding to respiration inhibition rates from 2.7 to $60 \%$ (figure $3 \mathrm{~b}$ ). 
The effective concentration that inhibits by $50 \%$ the respiration rate of microorganisms in activated sludge $\left(\mathrm{CE}_{50}\right)$, for the case of crystal violet depends on the nature of the activated sludge tested being $22.39 \mathrm{mg} / \mathrm{L}$ for the tested conventional activated sludge and $33.88 \mathrm{mg} / \mathrm{L}$, respectively, for the aerobic granular sludge (figure 3).

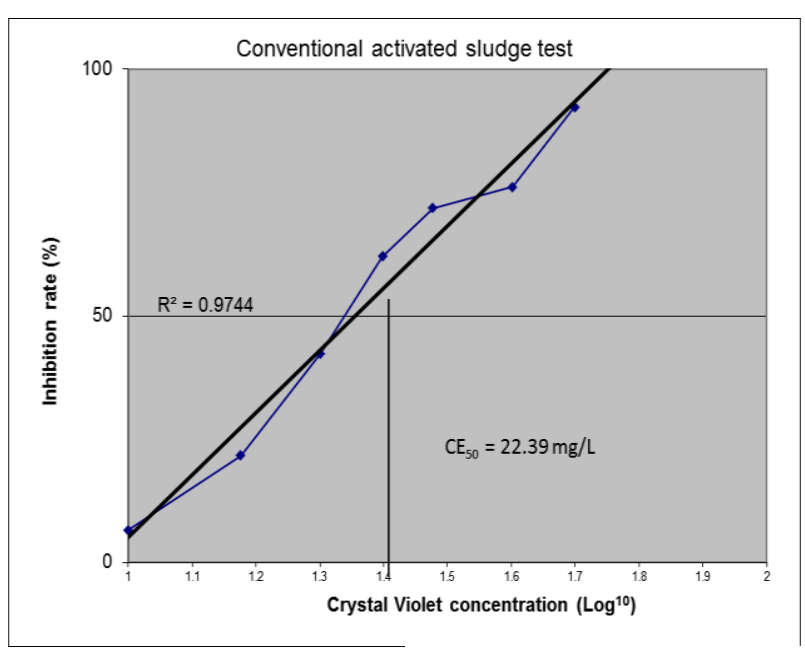

a)

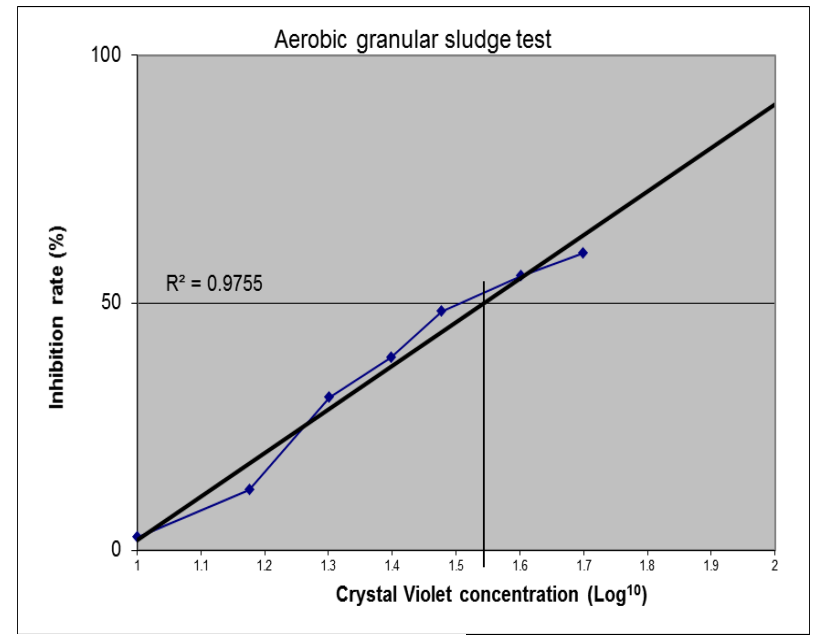

b)

Fig. 3. Comparative representation of inhibition rate of crystal violet on the respiration of activated sludge ( $\mathrm{a}$ - conventional sludge; $\mathrm{b}$ - aerobic granular sludge)

\section{Discoloration experiments}

Immediately, during feeding and after initial mixing we may observe that most of the crystal violet of the influent is being absorbed in the matrix of aerobic sludge granules. Analyzing the images presented in figure 4, we can appreciate that the processes underlying the discoloration of wastewater with crystal violet are both physical, initially by adsorption and absorption in the matrix of aerobic sludge granules, and biological, as emphasized on one hand by the fact that the color of the granules returns to the initial yellow-brown color within a few hours, and on the other hand by the evolution in time of crystal violet concentration in the reactor and the residual concentration in the final effluent.

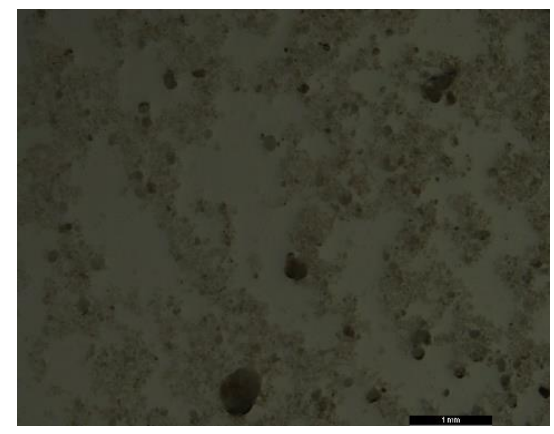

a)

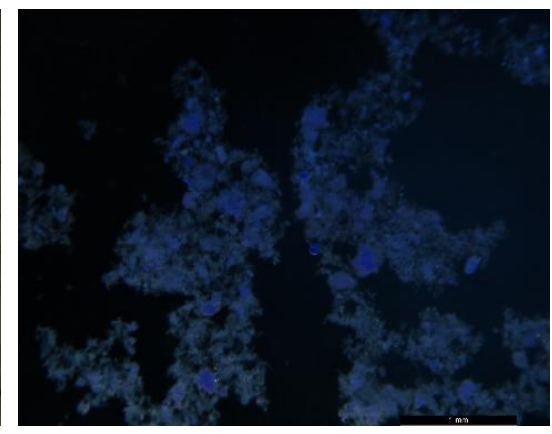

b)

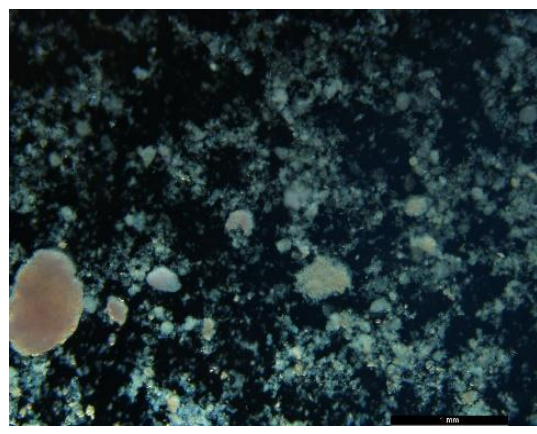

c)

Fig. 4. Stereomicroscopic images of granular aerobic sludge. a) Control before feeding with Crystal Violet, b) Immediately after feeding with Crystal Violet, c) After 8 hours, at the end of the treatment cycle

The evolution in time of crystal violet concentration was monitored hourly for two operating cycles of the sequential bioreactor with granular sludge. The initial concentration of crystal violet in the influent was 10 and, respectively $15 \mathrm{mg} / \mathrm{L}$. The volume of influent added was $2 \mathrm{~L}$ representing an SBR exchange ratio of 50\%. In both cases, the treatment response was similar (figure 5), which highlights the adaptability of granular sludge to the toxic substrate at this level of concentrations. 
Granular sludge is less susceptible to Crystal Violet toxicity because most of the microorganisms in the granular biomass are not exposed to the high levels of pollutant concentration existing in the influent. The aerobic granules have an excellent ability to discolor the Crystal Violet dye. In the presence of sodium acetate as co-substrate, significant decolorisation and removal efficiencies above $95 \%$ have been observed.

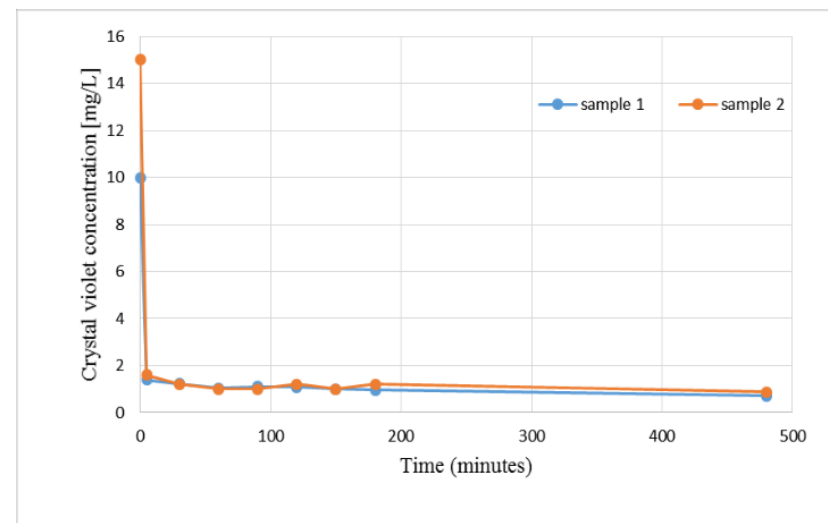

a)

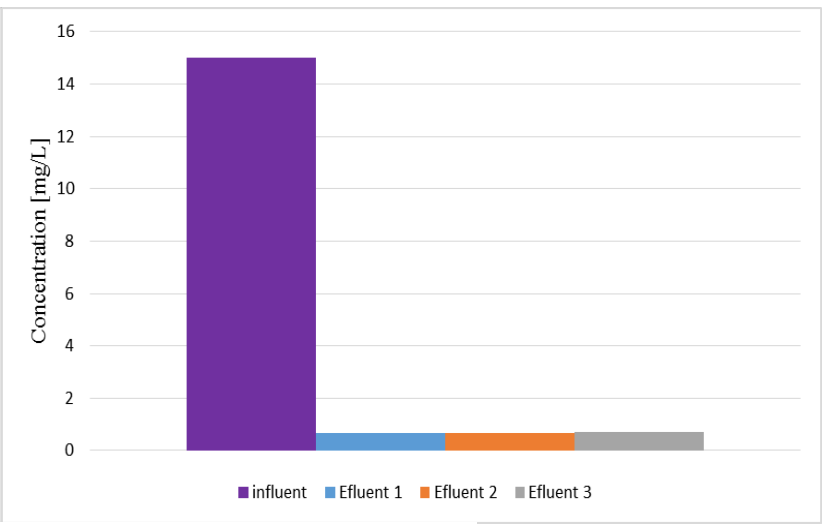

b)

Fig. 5. Evolution in time of Crystal Violet concentration (a); Comparative concentration of Crystal Violet in the effluent and influent (b)

\section{CONCLUSIONS}

Even though inhibition tests were performed in similar conditions, the $\mathrm{CE}_{50}$ of crystal violet in a system with aerobic granular sludge is approximately $50 \%$ more than the $\mathrm{CE}_{50}$ of the same pollutant for a system with conventional sludge. Thus, the microorganisms of aerobic granular sludge are less susceptible to the toxicity of influent pollutants than the suspended/floc microorganisms in conventional sludge. The high tolerance of aerobic granules can be exploited in the development of compact wastewater treatment systems with high concentrations of dyes and sudden variations in loadings. Crystal violet at concentrations of up to $15 \mathrm{mg} / \mathrm{L}$ is readily biodegraded in an aerobic granular sludge SBR system in the presence of acetate as co-substrate within a treatment cycle of 8 hours.

\section{ACKNOWLEDGEMENT}

The work was funded by the Ministry of Research, Innovation, and Digitalization of Romania through Programme Nucleu, contract no. 20N/2019, Project code PN 19040301.

\section{REFERENCES}

[1] DOCAMPO, R., MORENO, S.N., Drug Metab. Rev., 22, no. 2-3, 1990, p. 161, doi:10.3109/03602539009041083.

[2] MALEY, A.M., ARBISER, J.L., Exp. Dermatol., 22, no. 12, 2013, p. 775, doi:10.1111/exd.12257.

[3] HARIFI-MOOD, A.R, HADAVAND-MIRZAIE, F., Chem. Spec. Bioavailab., 27, no. 1, 2015, p. 8 .

[4] REHMAN, F., MURTAZA, S., ALI KHAN, J., KHAN, H. M. J. Chil. Chem. Soc., 62, no. 1, 2017, p. 3359, https://dx.doi.org/10.4067/S0717-97072017000100011.

[5] ZHANG, F., FENG, C., Li, W., Cui, J., Int. J. Electrochem. Sci., 9, 2014, p. 943.

[6] MONDAL, S., Environ. Eng. Sci., 25, 2008, p. 383.

[7] AL-MOMANI, F., TOURAUD, E., DEGORCE-DUMAS, J., ROUSSY, J., THOMAS, O., J. Photoch. Photobio. A, 153, 2002, p. 191. 
[8] MANENTI, D.R., SOARES, P.A., SILVA, T.F., MODENES, A.N., ESPINOZA-QUINONES, F.R., BERGAMASCO, R., BOAVENTURA, R.A.R., VILAR, V.J.P., Environ. Sci. Pollut. Res., 22, 2015, p. 833, https://doi.org/10.1007/s11356-014-2767-1.

[9] ZEHRA, T., PRIYANTHA, N., LIM, L.B.L. Environ. Earth Sci., 75, 2016, p. 357, https://doi.org/10.1007/s12665-016-5255-8.

[10] REHMAN, F., SAYED, M., ALI KHAN, J., SHAH, L.A., SHAH, N.S., KHAN, H.M., KHATTAK, R.Z., Phys. Chem., 232, no. 12, 2018, p. 1771, https://doi.org/10.1515/zpch-20171099.

[11] ABDI, M., BALAGABRI, M., KARIMI HOSSINI, H.H,. RASTEGAR, S.O., Appl. Water Sci. 10, 2020, p. 168, https://doi.org/10.1007/s13201-020-01252-w.

[12] LIN, Y., HE, X., HAN, G., TIAN, Q., HU, W., J. Environ. Sci., 23, no. 12, 2011, p. 2055, doi: 10.1016/s1001-0742(10)60643-2.

[13] MOHANTY, K., THAMMU NAIDU, J.B., MEIKAP, C., BISWAS, M.N., Ind. Eng. Chem. Res. 45, no. 14, 2006, p. 5165.

[14] JASSAL, P., RAUT, V., Water Resour. Manag., 196, p. 495, doi:10.2495/WRM150421.

[15] PARShETTI, G.K., PARSHETTI, S.G., TELKE, A.A., KALYANI, D.C., DOONG, R.A., GOVINDWAR, S.P., J. Environ. Sci., 23, no. 8, 2011, p.1384, doi:10.1016/s1001-0742(10)605475.

[16] AYED, L., CHERIAA, J., LAADHARI, N., CHEREF, A., BAKHROUF, A., Ann. Microbiol., 59, 2009, p. 267, https://doi.org/10.1007/BF03178327.

[17] BUMPUS, J.A., BROCK, B.J., Appl. Environ. Microb., 54, no. 5, 1988, p. 1143, doi:10.1128/AEM.54.5.1143-1150.1988.

[18] KUNJADIA, P.D., PATEL, F.D., NAGEE, A., MUKHOPADHYAYA, P.N., DAVE, G.S., BioResources, 7, no. 1, 2012, p. 1189.

[19] SAHBAZ, D.A., DANDIL, S., ACIKGOZ, C., Water Qual. Res. J., 54, no. 4, 2019, p. 299, https://doi.org/10.2166/wqrj.2019.049.

[20] WANG, H.J., DONG, W.Y., LI, W.G., YIN, W.C., TAO, X., Huan Jing Ke Xue, 29, no. 10, 2008, p. 2856.

Citation: Bumbac, C., Manea, E.E., Tiron O., Removal of crystal violet from aqueous solutions using an aerobic granular sludge system, Rom. J. Ecol. Environ. Chem., 2021, 3, no. 1, pp. 55-60.

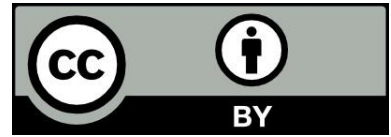

(C) 2021 by the authors. This article is an open access article distributed under the terms and conditions of the Creative Commons Attribution (CC BY) license (http://creativecommons.Org/licenses/by/4.0/). 